\title{
SOCIALLY ORIENTED NGOS AND SLOCAL COMMUNITIES IN A RUSSIAN REGION: WAYS TO BUILD UP THEIR RELATIONSHIP
}

\section{Nina Ivashinenko, Alla Varyzgina}

Nina Ivashinenko is professor of economic sociology at the National Research Lobachevsky State University of Nizhniy Novgorod and an Honorary Research Fellow at the School of Social and Political Sciences, University of Glasgow. Address for correspondence: Universitetskii per. 7, Nizhniy Novgorod, 603000, Russia. nina.ivashinenko@glasgow.ac.uk.

Alla Varyzgina is a lecturer in the Faculty of Social Sciences, National Research Lobachevsky State University of Nizhniy Novgorod. Address for correspondence: Universitetskii per. 7, Room 209, Nizhniy Novgorod, 603000, Russia. varyzgina@mail.ru.

This article concerns the issue of interactions between socially oriented nongovernmental organizations (NGOs) and families with socially disadvantaged children whom such organizations are seeking to help. In the Russian regions, especially in rural areas, the employment of modern concepts in the investigation of NGOs as driving forces and results of social activities of the population revealed that these organizations often function quite separately from the community and maintain close links to government social services providers. We analyzed a wide range of factors that could decrease the gap between NGOs and the population. To investigate this issue, we used the results from several international research projects conducted by an international team in Nizhniy Novgorod Oblast in 2010-2015. Nizhniy Novgorod Oblast can be viewed as an average Russian region in terms of social and economic development. In our research, we invited leaders of NGOs-mainly those providing support to families-from several districts of the region and local families already in contact with NGOs. We also invited those who could potentially be interested in this cooperation, such as families with many children, families in difficult situations, and foster families. Based on our findings, we argue that relationships between $\mathrm{NGOs}$ and families depend on contributions from both sides. On the one hand, these relationships are shaped by the internal situations of NGOs, including the specifics of their creation, their ways of cooperation with state organizations, their funding sources, and the types of services they provide. On the other hand, the level of trust, the attitudes of people towards $\mathrm{NGOs}$, the experience of engagement with particular NGOs, and the development of social networking within local communities also create some barriers and opportunities for cooperation between people and NGOs. Investigation of the mutual links between $\mathrm{NGOs}$ and different social groups can be helpful for understanding the development of the third sector in Russia as a whole and might provide valuable insights for NGO activists who would like to improve their activities.

Keywords: NGOs; Local Community; Grassroots Activities; Social Services for Families 
Nongovernmental organizations - called noncommercial organizations in Russiahave, since the collapse of the USSR in the early 1990s, become the focus of research projects following the establishment of a new socioeconomic and political system in the country. There are now academic works devoted to the similarities and differences between Russian NGOs and their Western counterparts and to their respective roles in democratic processes (Richter 1998; Henderson 2002; Howard 2003; Evans, Henry, and Sundrom 2005). More recent work investigates how the third sector in Russia is functioning and developing alongside public social services such as social care, education, and medicine (Iakimets 2002; Teodorovich 2009; Sokolov 2013; Bindman 2015; Tarasenko and Kulmala 2016). Russian governmental policy has placed greater emphasis on supporting NGOs that provide social services, rather than other third sector organizations, which may be involved in political activities. As a case study for understanding the relationship between NGOs and local communities, we focus on NGOs working with families and socially disadvantaged children. In Nizhniy Novgorod Oblast at the beginning of 2016, there were 250 such organizations; 14 percent of them worked with families and social orphans (children who have biological parents but are left without parental care for some reason, for example, because their parents are terminated in their parental rights) and were included in the register maintained by the Ministry of Regional and Municipal Policy. These kinds of NGO activities are more developed in Nizhniy Novgorod than other sectors (Nikula and Ivashinenko 2017). Our aim is to investigate how NGOs make connections and develop their relationships with families who potentially need their assistance.

\section{THE ROLE OF NGOS IN CIVIL SOCIETY}

The dominant position of the state in Soviet society was a crucial factor for the functioning of all social systems in the USSR. Socioeconomic and political transformations in post-Soviet societies have created conditions where new institutions such as NGOs can emerge, which, in turn, could form the basis for new social dynamics. Initially, researchers focused on the issue of the independence of NGOs from the state (Hale 2002). Many studies have taken for granted that NGOs are representatives of the local population and the voice of civil society (Cook and Vinogradova 2006; Crotty 2009); a civil society that has been "characteristically understood as a counterweight to the state" (Kulmala 2011:51). Subsequent research, including our own studies, has shown that the binary opposition between the state and civil society is challenged by questions surrounding the nature of the actors that compose civil society (Loktionova 2012). In this article we argue that to grasp a deeper understanding of the situation in Russian civil society it is vitally important to investigate not only state-society interactions (Cheskin and March 2015), but also the relationship between NGOs and citizens linked by common interests and collective activity.

The shift in perspective of international scholars from the political role of civil society in Russia to its role in the development of social services has produced detailed analyses of the nature of existing NGOs in Russia. Scholarly literature usually 
distinguishes between two types: government-organized nongovernmental organizations (GONG0) (Hemment 2012) and grassroots social service organizations (Kay 2000). The term GONGO is often employed in a political context to highlight the dependence of these organizations on state policy and priorities and their consequently weak political positions. However, the transmission of this terminology from the political to the public sphere changes the focus of investigation from political independence to the effectiveness of the relationships these types of nonprofit organizations have with social groups looking for assistance. The term "grassroots organizations" also has a broad range of interpretations depending on the particular context: "Grassroots social service organizations are particularly well suited with their small neighborhood connections driven by community members to carry out the self-help approach to community development" (Fisher 2013:295). Within our research, the term grassroots NGO is employed to highlight the fact that these organizations were created by individuals or groups of people with no connections to government bodies, who established their organizations to meet their common needs.

The organizational culture of NGOs and their relationships with local communities have been well-documented globally, although researchers in Russia have only recently started paying attention to this topic (Anheier 2000). Organizational cultures and relationships are highly dependent on local context, especially in countries that have experienced major political and socioeconomic transformations. The organizational culture of NGOs and their relationship with local communities in Russia have only recently been the subject of academic debates focusing on the problem of leadership (Henry 2006), motivations for voluntarism (Kosova 2012; Kiseleva 2013), and the network structure of NGOs. We understand the relationship between NGOs and their target social groups as complex, fluid interactions based on differing attitudes and perceptions on both sides. We would like to compare the perspectives of both NGO representatives and of families in need on their interactions. The openness of NGOs' interactions with other actors demonstrates a willingness and readiness for these organizations to work with local people and understand their needs and interests, rather than providing the formal services that would be received within the framework of a government program. The specifics of relationships between NGOs and families are dependent on various factors, such as ways of creating organizations, features of teams and the leader's position, and the range of services offered to clients, along with the mechanisms used for recruiting new members and how they advertise their activities.

\section{RESEARCH FIELD}

The article is based on findings from several international research projects from the Finnish Centre of Excellence in Russian Studies, Aleksanteri Institute, University of Helsinki; Uppsala Centre for Russian and Eurasian Studies, Uppsala University; and the Department of Economic Sociology at Lobachevsky State University of Nizhniy Novgorod. Conducted between 2010 and 2015, these research projects addressed the fields of welfare, local development, population quality of life, and poverty reduction. 
Interviews were conducted in cities and small towns (both distant and close to the regional center) within Nizhniy Novgorod Oblast, which helped us to generate a broad view of the region as a whole. We conducted semistructured interviews with both staff and volunteer activist representatives from 15 randomly chosen NGOs, located throughout the region, that provide social services for children, large families, vulnerable and poor families, and foster families. We also interviewed five informants supporting NGOs and their social activity (all of whom were mentioned in the interviews with NGOs), and semistructured interviews with representatives from 52 families, selected through snowball sampling, who were either NGO clients or who indicated a willingness to engage with NGOs.

Nizhniy Novgorod Oblast can be viewed as an average Russian region in terms of its socioeconomic milieu, including levels of social activity and third sector development. The Ministry of Regional and Municipal Policy maintains a register of self-organized NGOs (SONGOs) that at the beginning of 2016 included 250 organizations. (For more details about the region, see Ivashinenko and Rimashevskaia 2013.) Merging the results of different projects over the space of five years allows for a deeper understanding of the relationship between NGOs and their target assistance groups.

\section{FOUNDING HISTORIES AS A FACTOR IN BEGINNING RELATIONSHIPS WITH POPULATIONS}

Russian NGOs can be divided into two major categories: firstly, NGOs formed in the 1990s with institutional support from different types of sponsors (for example, enterprises), which are sometimes under grant programs, and secondly, self-organized NGOs. An example of an institutionally based NGO would be the "old formed" NGOs, which were set up before perestroika and survived despite the shuttering of other groups such as veterans' councils, women's councils, and committees or branches of international organizations following restrictions on Russian government activities. Self-organized NGOs often emerge because of the activity of a particular person or groups of people who share similar interests and needs. The institutionally based NGOs more often have connections with governmental bodies and better access to resources than do self-organized NGOs. The institutionally based NGOs usually have branches in different regions and are involved not only in local-level activities but also in nationwide networks and events all over Russia. When discussing their organizations' formation, the activists often referred to certain traditions of their organizations and well-known characteristics of their activities: " [Our organization] was created almost 30 years ago. It consists of the Ombudsman for Children's Rights, a Federal Migration Service officer, the vice minister of culture, a head of the regional registry office, and a head of the women's association" (Interview with a representative from a women's council NG0).

The gap between institutionally based NGOs and their clients tends to be quite wide due to the specifics of their establishment as part of state services, which went through difficult times during the political reconstruction in Russia that began with the transformation of the political system in the late 1990s. As they were connected 
to the previous state structure, they are often perceived by representatives of NGOs as old-fashioned and primarily focused on state interests rather than peoples' needs. The restoration of these organizations after perestroika took some time. However, the logic of the system functioning in Russia created some fruitful conditions for the reproduction of certain organizations that cooperated more freely with governmental bodies due to similarities in management structure.

In contrast, self-organized NGOs lie on the opposite end of the NGOs spectrum, as they were created through the enthusiasm of particular people or groups who became a part of the history of these organizations. Activists prefer to highlight the human features of their founders, such as their high standards and willingness to help others, when discussing their creation: "The main thing in my charity work is family values. Since I was a child, my parents taught me that one ought to help people. They taught me compassion" (Interview with a representative of a children's charity NGO).

In this case, the cooperation between self-organized NGOs and families who need these services mainly depends on the primary networks of founders of these NGOs and on the personal willingness of their leaders to widen their activities:

In 2007, when foster families appeared, and we had difficulties communicating with officials, so we attracted parents, the most active ones. In the beginning, parents created an Association of Foster Families of Nizhniy Novgorod Oblast; they joined to be together, to solve the same problems as an NGO, and make it easier to communicate with officials. (Interview with a representative of a selforganized NGO for foster families)

Fairly renowned associations of families with many children or parents with disabled children have formed their own NGOs based on their shared interests and needs. The process of formalizing their activities mainly depends on access to different types of resources and grant programs. Without formal registration certain kinds of financial help cannot be received (Benevolenski 2014). The opportunity for other families with disabled children to join these organizations (both as members and as clients) depends to a large extent on their children's medical diagnoses and particular locations; for example, the majority of these organizations is located in regional capitals and is not always easily accessible for families living in rural areas.

By comparing the basis of institutionally formed and self-organized NGOs, we can argue that initially the first ones were created on the basis of client-patron relationships, while those that followed tended to be network oriented. However, the self-organizing nature of NGOs cannot guarantee the full disclosure of their interactions with other people. It cannot be taken for granted that grassroots organizations tend to be less bureaucratic than those that are institutionally based. Self-funded NGOs can also suffer organizational conflicts due to the interpersonal relationships between different group members, such as old members and newcomers, between those with compensated and fully voluntary jobs, and over money distributions through grants. Several of the NGO activists mentioned that these conflicts occurred at the outset or in the middle of their organizations' histories: "The association ex- 
isted, but there was trouble with it; one parent came to power there and made decisions on her own. We therefore decided to just quit the association and to leave everything as it is, but it happened to collapse" (Interview with a representative of an NGO for foster parents).

The history of the NGOs' transformation-which could be the subject of further investigation - contains some examples of institutionally based NGOs becoming enriched by informal network resources, due to the inclusion of members of self-organized NGOs: "We came to the Ministry of Education and told them that we were engaged in the same activity. Could we somehow collaborate together?" (Interview with a representative of a children's NGO 1).

In contrast, some self-organized NGOs were transformed into funds with paid employees and a less informal operational process. The model of NGOs' interactions with members and clients is inherited from the organizational culture of these groups, which was formed from the outset. The interaction can be divided into two types: "service for a wide range of clients" and "assistance for close members." The implementation of both models impacts the future relationship between NGOs and the local population.

\section{RANGE OF SOCIAL SERVICES PROVIDED AND SCALE OF CONTACTS WITH CLIENTS}

The popularity of certain NGOs among the local population seems to depend on the range of services provided and the targeted social groups. Today the set of social services that can be provided by NGOs has been increased significantly according to the 2015 Order of the Government of the Russian Federation No. 1738-r, which approves the standard of the development of competition in the territorial subjects of the Russian Federation. NGOs have also received the right to work in educational services, social support, entertainment, and medical assistance. However, despite having been granted rights over these social activities, NGOs have struggled to obtain the necessary resources to provide services. It is a rather interesting contradiction of the process that should be investigated further.

NGO activists divided their activities into one-off events (holiday events for children, sporting events, or one-time support for pensioners or families) and regularly occurring activities. According to NGO activists' opinions, organizing individual events is fairly straightforward and does not require many resources. There is no need to meet special requirements established for providing social services. The scale of one-off activities ultimately depends on the availability of resources. These events can be organized by small groups of volunteers or by paid staff. Social events could be widely advertised or, in contrast, have only network support. The NGOs involved in our studies spoke of events they had held with pride: "We have some projects and events, and they can be devoted to some holidays. Here, today's event is dedicated to the Day of Love, Family, and Loyalty, and we will honor the best families of Nizhniy Novgorod Oblast" (Interview with a representative of a women's council NGO). 
As per the respondents' replies, the events were aimed at promoting family values and supporting successful marriage, and this drew attention from a broad audience of people who had not previously had contact with NGOs. These types of events can receive support from the local and regional government more regularly than others-not only gifts and food can be provided but also some public relations support. However, participants seeing NGOs and government agencies working together tend to pay more attention to the traditional role of state actors and rarely mention the role of NGOs in these processes. For example, other respondents answering questions about the celebrations did not mention the role of NGOs.

The irregularity of these social activities can also provoke some doubts about NGOs' effectiveness in solving social problems. The respondents' prevailing attitudes towards social events organized by volunteers demonstrated perceptions of NGOs as being somewhat unstable and frivolous. The public is aware of these activities but does not attach significance to the NGOs: "We do not just organize shows or events, don't post our activity reports. We have everyday activities: washing floors, collecting diapers; we work for parents and for children" (Interview with a representative of a children NGO 2).

The routine services provided by socially oriented NGOs are not as popular among local people and do not engage with the interests of a large number of families. The NGOs carrying out these activities complained about not receiving special support from the government as they were "doing their job," and they did not engage a broad spectrum of people who could be deemed to be the potential electorate: "I believe that it is great to be an organization for social services, but only if the state will change its attitude to child policy, to nonprofit organizations' activities..." (Interview with a representative of a children NG0 2).

In Russia the provision of social care and support has historically been perceived by the population to be a primary responsibility of the state. The majority of the population views the Russian government as a central actor in social services (Ivashinenko 2014). When governmental bodies attempted to transfer some of their previous duties to nongovernmental organizations, they were met not only with barriers to resources - such as lack of financial support and professional knowledge of NGOs-but also a lack of trust from the population towards NGOs (Mersiianova and Iakobson 2009). Receiving social services can make a dramatic difference in the lives of families who are in need of social support, but according to the opinions of respondents, NGOs are not fully established organizations capable of providing these services without governmental control and support.

Russian socially oriented NGOs who provide a broad range of social services are at the beginning of the formation of their public image, which partially depends on the type of services they provide. Vital facilities for the local population could be focused on small, vulnerable groups who do not need special informational support. In contrast, some social events could be widely advertised but perceived as less important. 


\section{NGOS' PRINCIPLES AROUND WORK WITH LOCAL POPULATIONS}

Depending on the types of activities provided, different NGOs use a wide range of mechanisms for working with different social groups and local communities. Starting by assisting their primary activists and members, self-organized NGOs then moved on to servicing wider groups who could be invited to participate in networking processes. However, the power distributed through these networks depends on the network structure and actors participating in this process. As some respondents remarked, NGOs are more mobile than governmental bodies and can therefore cooperate with different organizations and provide special services for families. These collaborations can give NGOs the opportunity to exchange information about families in need or receive access to official registers of social benefits recipients: "As head, I can communicate and have partnerships with other NGOs who also deal with families, as well as other types. We can do this together with state institutions, the Ministry of Education, local institutions, schools, kindergartens, and orphanages" (Interview with an NG0 for large families 1).

Official social services, such as education or health departments, have their own audience of clients, which can be shared with NGOs under the aegis of special projects. By cooperating with official social services NGOs can extend their own circle of customers. However, $\mathrm{NGO}$ s risk being perceived as part of the governmental system if they involve people in their activities through this official channel.

In this scenario, NGOs can be perceived as controllers rather than assistants. There are still many questions about how to strike a balance between official standards for social service providers, on the one hand, and flexible and innovative volunteer work, on the other. NGO activists involved in our projects understand the advantages and disadvantages of this approach when looking for potential clients. Moreover, according to them, cooperation with governmental organizations tends to be an important factor when obtaining permission to work with vulnerable people. $\mathrm{A}$ number of grant programs also have requirements that a certain number of beneficiaries be involved in applied projects.

To avoid this difficulty, some NGOs prefer to cooperate with other nongovernmental organizations, including commercial ones, who work in similar fields. However, rivalry and interpersonal communication problems are just two invisible barriers facing those who use such strategies. Respondents did not directly mention any competition between NGOs applying for similar grants, but this could be read between the lines of many interviews. Successful cooperation between NGOs was usually mentioned in the frame of events that brought members and clients together. Common, routine work requires a certain type of coordination, but a narrow circle of NGOs needs a good management team:

I think every organization deals with its own problems; there were some attempts to unite, but as a rule, in my opinion, it was more formal. In spring, we hold joint events with a women's crisis center, but our two organizations help each other because we have big hearts. You can't however call it a partnership; I feel it's still a separate organization. (Interview with a representative of a children NGO 1) 
The relationship between $\mathrm{NGO}$ s and the local population can also be quite complex due to the socioeconomic situation in the Russian regions. NGOs that try to organize advertising of social programs and events to support social norms and values are met with the shrinking informational horizons of local people. Families in difficult situations have other priorities and expect assistance in some fields that are not always the jurisdiction of NGOs: "There is a shortage of financing, poverty, and there is nothing to conceal-people lose their jobs; and to attract donors? This is our common problem, we need to create new job positions because people lose their jobs and have nothing to eat" (Interview with a representative of a women's council NG0).

Public opinion supports traditional family values and programs aimed at their promotion (VTsIOM 2016). However, current economic difficulties have moved this information to the back stage of people's everyday lives. As noted by several respondents, fascinating and well-organized events can receive weak support and a low level of participation from the local population due to the decline of public activities more generally.

Targeting support for families in need, socially oriented NGOs are trapped between two poles of public opinion. On the one hand, over half of those people are in a weak financial position-although they do not want to be perceived as poor-and avoid contacting other vulnerable people. On the other hand, poorer families often feel depressed and do not trust the majority of organizations who provide assistance to them. As representatives of NGOs working with families noted, "If you take a family in a difficult life situation, they are the most closed ones yet." The psychology and mental condition of these families probably require support from health specialists. They are more passive than other social groups not only in terms of self-organization but also when searching for possible assistance (Fell and Hewstone 2015).

At the beginning of the process of shaping their public image, NGOs had to overcome their own problems and stigmatization of their members. For example, there could be a perception that poor or large families are undeserving of assistance (Varyzgina and Kay 2014) or that foster parents are only interested in receiving payments on behalf of the children they care for.

Public attitudes towards underprivileged social groups have now started to shift to a more positive outlook. However, these processes need significant reconsideration of the attitudes and stereotypes among people belonging to particular social groups. Respondents noted self-organization among parents of disabled children was relatively quick compared to others. Their active position drives the creation of a barrier-free environment and inclusive education:

Parents of children with disabilities become independent; they organize selfsupport groups, and they became active. Large families broke the barrier long ago. Yet foster families are still afraid that someone would take their children away from the family, and are afraid to articulate their problems, fearing interventions from outside. (Interview with an NG0 for large families 1) 
In Nizhniy Novgorod Oblast an association of mothers of many children is perceived by respondents to be quite a successful organization that has overcome stigmatization and created a positive public image. New social groups of foster families united by their specific needs have also encountered similar problems. According to NGOs working with foster families, the families often cannot fully understand governmental bodies' duties and avoid any unnecessary contact with them to prevent any challenges to their foster care activities. The foster parents' mistrust of governmental bodies that regulate foster care creates barriers to engagement of these families in communications with organizations, including NGOs.

As they work with different social groups, NGOs create unique environments where people of various backgrounds can meet and break down the barriers between them. Groups of members who have successfully overcome financial and psychological difficulties share their experiences and help other families in difficult situations.

This situation is completely the opposite of the client-based approach whereby NGOs provide services and clients use them. The organized relationship is partly based on participatory approaches: families in difficult life situations are encouraged to participate in the process of overcoming poverty. The development of partnerships among families of different socioeconomic statuses generates greater tolerance towards people in poverty.

The financial backing of NGOs is a major factor in their development, but it is quite closely related to client-oriented approaches. Further evolution of cooperation between NGOs and their potential clients and volunteers tends to depend on changes in public opinion and on the tangled process of the organizational culture of $\mathrm{NGOS}$, as they can enrich each other.

\section{PUBLIC ATTITUDES TOWARDS NGOS AND SOURCES OF INFORMATION ABOUT NGOS}

Studies over the last decade have indicated that the level of public involvement in third sector activities remains low, which to a large extent is due to the limited information about NGOs readily available to the Russian people (Blonin, Ivashinenko, and Strelkov 2008; Levada-Tsentr 2012; Sokolov 2013). The level of general participation in NGO activities is considered by researchers to be an indicator of civil society development. Families with children-including low-income families-had little or no experience dealing with NGOs either as clients or as volunteers. Many of them did not even know of the existence of such organizations or of the types of assistance they could provide (Teodorovich 2009; Varyzgina 2014).

Analysis of interviews with informants representing families shows that their attitudes towards $\mathrm{NGOs}$ are, to a certain extent, determined by stereotypes circulating in the public realm. We encountered two recurring stereotypes during our research, which were connected to perceptions of people's motives for participating in NGO activities and related to what people perceived were the powers available to $\mathrm{NGOs}$ and their ability to influence problems. Founders' motives for creating NGOs are often seen to be rather ambiguous. Some were thought to hold a sincere desire to 
help others, while others were considered to be motivated by self-interest and desire for money (similar attitudes have been noted by other researchers [Abramova and Sukhushina 2015]). Some people we talked with, who could be potential recipients of NGOs' services or volunteers, had rather positive perceptions of NGOs and their leaders, mentioning that they were enthusiastic and altruistic people willing to help others: "I'm not a member, but I believe they are wonderful people who work there" (Interview with a young mother 1 ).

People who shared such attitudes are not always involved in NGOs activities, and sometimes they do not know the names of any organizations or the work that they do, but have a rather general understanding of volunteer activity. Nevertheless, such people are usually civically active, although not all of them recognize their activity as being civic. They often help others in need or participate in spontaneous actions like gathering food or clothes for those in desperate need. Civically active people to a certain extent project their personal attitudes, motives, and willingness to help others onto leaders and members of NGOs. As some studies show, people with extensive social ties are more likely to trust other people (Putnam 1995). The reverse applies to people who are reticent and believe that "everyone is out for himself," as a young mother put it, having a low level of social trust and a cautious attitude towards NGOs. Many of them were sure that some NGOs did not maintain the nonprofit ideals of their creation, relating mainly to charity organizations. As one young mother said, "There were many dishonest things there." One of the reasons for such attitudes could be the skepticism many vulnerable and poor families feel about rich people creating NGOs to share their money in order to help strangers: "Charity is poorly developed. If there were more rich people creating NGOs not to launder money but to help, it would be great" (Interview with a young mother 2).

Informants from this group are usually not involved in NGO activity, with most of them never actually having contacted NGOs. People who share such stereotypes are not usually civically active and do not share the ideal of "helping yourself." At the same time, the idea of "organizations based on mutual help, where people come together to help each other" was met with a positive response, although many people were not ready to be involved in such activities.

Another stereotype that we came across in our study related to perceptions of the powers available to NGOs and their ability to influence problems. Here again people are divided into two major groups. The first group believed that people could manage to solve almost any problem if they combined their efforts (be it through an informal or formal organization). Those who believe NGOs could influence problems and solve them often become active participants in NGO activities or even leaders of such organizations. The other (larger) group of people doubted NGOs could solve the financial problems of their clients or significantly improve their situations and therefore did not see much use in contacting NGOs: "I didn't try. Why? It's just a waste of time. You won't get much" (Interview with a female pensioner).

Attitudes towards NGOs are to a large degree determined by the level of a person's civic activity - the extent to which they are involved in the reciprocal exchange of help/support/advice. Those who are civically active-who are willing to provide 
some assistance and support to other people-are more likely to have positive attitudes towards NGOs, even if they do not know much about such organizations and how they work. Civically passive people, those who are indifferent to others' problems and focused on their own situation, more often have an ambivalent or negative attitude towards NGOs, as they believe NGOs do not have the power to influence the lives of vulnerable families and also doubt the altruism of members' motives. Such attitudes correlate with a generally pessimistic perception of their life and a high level of discontent. These respondents often do not know much about NGOs and cannot mention any concrete examples of, for instance, NGO corruption. The proportion of identified types of attitudes could be the subject of further research. Moreover, here lies another very interesting issue relating to sources of information about NGOs and their activities available to the local population in crisis situations that shrink people's informational horizons. Sources of information were not often obvious; sometimes people just mentioned that they had "just heard about it somewhere." Still, the majority of NGO clients obtained information about NGOs' activities mainly through interpersonal communications with friends and relatives.

A rather special type of personal communication was when families were contacted by representatives of institutions providing social or medical services. Although there are no well-established partnerships between such institutions and NGOs, social workers or doctors often privately share information about NGOs they know personally with their clients if they feel it would benefit them in some way. They could offer their personal advice to contact some NGOs, but they seldom specified what kind of support or assistance families could count on. As mentioned above, there is a risk that NGOs are perceived as being part of governmental systems and thereby inherit public attitudes about public services. Interpersonal communication and social network inclusion are now more widespread sources of information than public information sources.

People's attitudes towards NGOs are to a large degree determined by the level of their civic engagement. Those who already have experience helping other people seem more likely to have positive attitudes towards a wide range of NGOs, even if they do not know much about any particular organization and have only a general understanding of NGOs' activities. They often become active participants in NGO activities or even leaders of such organizations. Attitudes to NGOs are connected to perceptions of people's motives for participating in NGO activities and to perceptions of the powers available to NGOs and their ability to influence problems.

\section{EXPERIENCES OF FAMILIES' CONTRACTS WITH NGOS AND CHANNELS OF FAMILIES' INVOLVEMENT IN NGO ACTIVITIES}

Families regularly receiving assistance or using NGO-provided services esteem their activity as being very positive. As a rule, they have personalized, long-term, friendly relationships with members of organizations, which create the basis for mutual trust and are the foundation of family involvement in NGOs' activities. Families have a very positive perception of NGO services in the field of early or extracurricular education 
for children and the organization of children's leisure activities: "It was great when we used to visit the club. The children had been waiting to go and we really loved it. Once every two months we used to go, the whole family; even when we used to live far away, we were invited" (Interview with a foster mother, member of an NGO for foster parents).

There are some prevailing perceptions among families regarding the kinds of problems NGOs could deal with. The most widespread observations were that NGOs are the most efficient in activities that do not require much money (like organizing events and leisure activities, as mentioned above). Families who regularly apply to NGOs for help feel that they cannot solve problems that require large financial costs or more general problems like poverty reduction. At the same time, families rate as very positive one-time financial assistance or services provided by NGOs as solutions to specific needs. Families value the help and support received from NGOs, like onetime or regular financial support, children's clothes, and other goods they need. NGOs are evaluated as being rather efficient in the field of consulting and advocacy in interactions with authorities and governmental bodies or in some "paperwork questions." To manage service provision, NGOs mainly use personal contacts of NGO leaders with other NGOs and local entrepreneurs. Such sponsorship in the majority of cases is based on personal trust that NGO leaders "will use it in the right way as it was declared."

Most families communicate with NGOs as social services consumers, although there are some who use NGO facilities as a platform for communicating with one another. There are many examples of civic activity among families in the form of onetime actions and events. There are, meanwhile, attempts to organize family interactions on a regular ongoing basis, and NGOs can play a very important role supporting such grassroots initiatives (Banks and Hulme 2012). Occasionally, NGOs are initiators of such events, providing ideas for activities, organizing everything on their own, and sharing their office premises. There are cases when all initiative and organization of the process comes from families themselves, but still, their common feeling is that the work is being done on behalf of the organization. Single events can lead to the establishment of new grassroots NGOs.

The success of initiatives and the longevity of grassroots-organized groups and NGOs depend on several factors. One of these factors is the problem of a leader as an initiator of interaction. The leader of an NGOs can be a main driving force for organizational development. Quite often leaders of NGOs widely use their personal connections to maintain organizational activity, as well as when searching for financial support for the organization's projects (Tarasenko and Kulmala 2016). In many cases collaboration among NGOs is also based on leaders' personal social networks rather than on institutional or formal grounds. If, for some reason, an NGO leader quits, the situation can become unstable, and if there are no strong personal connections among organization members the collaboration can gradually diminish. When a leader leaves, the situation is very challenging for an organization. This situation was observed in a smaller scale child's group project, which was an efficient and in-demand service but closed shortly after the initiator of the project left: "The group 
only functioned for a year after its creation. And then I (the leader of the group) left on maternity leave. Another woman became responsible; she was asked to and agreed, but soon refused, and so the group was closed. It's a pity, of course" (Interview with a young mother going through a divorce).

The second factor, which can be a major obstacle, is the dilemma of finding a place to hold meetings and events. As a rule, self-organized NGOs (more often unregistered groups) do not have funding and cannot afford to rent a place. NGOs that have their own facilities and share them with self-organized NGOs (be they women's clubs and their tea parties or craft-making classes or needlework lessons) play an important role in supporting the existence of such groups. If an active group finds an opportunity to hold meetings at another $\mathrm{NGO}^{\prime}$ s facilities, they can continue functioning for quite a long time. Otherwise, their activity can rapidly fade:

There were some attempts to create a dating club in our district, where people could find a companion or friend. It did not survive though, as everything depends on money. Any project requires investments and if you are gathering people together, you need to rent a room. It is now very expensive. The longest period the club existed was around a year. The rest vanished much faster. (Interview with a low-income mother)

There are many positive examples of such cooperation. The decision to support initiatives of active people-especially when they are sharing premises-depends a great deal on the opinions of the organization members or employees when the group requires assistance. In this case, the members' or employees' attitudes towards a particular group activity is more significant in the final decision-making process than the organization's general position. Informal collaborations are more often successful if an NGO was organized from above and has enough space to share occasionally with active groups.

Some NGO leaders appreciate grassroots activity among the families they deal with and perceive them to be even greater evidence of their organizational success than the traditional quantitative indicators (budgets, the number of events, etc.). Heads of organizations greatly appreciate it when families who receive their support start becoming active in finding solutions to their difficult situations, as well as helping others in similar circumstances. NGOs try to encourage and to assist such initiatives, creating conditions for families to become involved in the process. Most families contact NGOs only if they need financial assistance or services but are not included in the mutual support networks of the NGO's family community. Those families who think that people could achieve more by combining their efforts, as a rule, become active members of nongovernmental organizations. The probability that families who contacted NGOs as consumers of services will become NGO members and become involved in NGO activities depends a lot on whether they have personal relations with other NGO members and are included in NGO social networks. If this is the case, families become active participants. NGOs play the role of facilitators of interactions and act as a platform for the creation of new social networks and the expansion of existing ones: 
I'm happy when they manage to do something on their own. And just receiving "thanks" (of consumers) is not the point. The key point is that they realize they can solve their problems by themselves, this is the most important thing, the most important result ... is when people-consumers turn into active participants/leaders. (Interview with a representative of an NGO for large families 1)

NGOs consider increased communication among families with their initiatives becoming real in the "NGOs environment" as the main result of NGOs agency:

There were passive youths in our district, and we tried to organize some a oneoff event. Now we have an active young group (aktiv). It was formed due to new contacts they got when they communicated during events. They have a room here for meetings, which is also a very important thing. Now they are very active, they organize some events for locals. (Interview with a representative of a TOS ${ }^{1}$ )

There are different strategies for involving the local community in social activity (Ivashinenko 2014). The first one, already analyzed in this article, is giving the floor to local initiatives and sharing rooms for meetings if required. Another strategy is offering families who come to NGOs some field of activity. Families could perceive this as a sort of free service exchange or as their assistance to the organization they applied to: "[For those who came as clients] we offer all kinds of activities as exchange for the services they get. They won't get money for it [their activities], but they can still help the organization if they want" (Interview with a representative of an NGO for large families 2).

As previously mentioned, NGOs invite the local community to participate in events they organize where there could also be opportunities to earn money; for example, mothers who have babies and therefore do not have the opportunity to work full time:

The idea of this event is for mothers to put their products on sale. These could be completely different products and services like tutoring services, handmade soap, miscellaneous goods, sewing, knitting, crafts, and so on. This shows mothers on maternity leave taking care of their babies that they still have opportunities. (Interview with a representative of an NGO for large families 1 )

Involving the local community in NGO activities usually comes down to existing contacts and relationships. These could be friends, relatives, neighbors, or connections via online social networks:

I invite parents, whom we know, to participate in the event. (Interview with a foster mother, member of an NGO for foster parents)

There was a club, which was originally for elderly women, but I see now they have begun to involve their granddaughters in studying needlework, basket weaving; it has already become their livelihood. They're exchanging their skills; later, daughters joined because it's profitable. (Interview with a representative of a low-income family 1)

${ }^{1}$ Territorial'noe obshchestvennoe samoupravlenie, in English "self-managed local association." 
Information about NGOs, services they offer, and their activities is usually spread via social networks in surrounding communities. Therefore, families excluded from the local community have difficulties in contacting NGOs because they do not have "the right people" to ask. These are usually people who require the support of NGOs the most, as they do not have a social network to rely on.

\section{EXAMPLES OF GRASSROOTS FAMILY ACTIVITY AND MUTUAL HELP}

Many families with children are potentially ready to participate in activities such as mutual assistance and support. There are certain types of activities families take part in:

- exchanging help (money, goods, or advice) with other families in difficult life situations;

- setting up clothing exchanges (there was one example of a web page created to facilitate this);

- holding meetings, clubs, or handicrafts classes (new skills could create or maximize opportunities to earn money);

- discussing problems;

- joining efforts in solving common, shared problems;

- organizing leisure and holiday activities for children, organizing trips;

- improving the environment and landscape;

- giving in-home assistance and care to elderly people (mainly endorsed by youth organizations).

In most cases, families' civic activity and mutual help are limited to their nearest neighborhood-family, friends, colleagues, neighbors — which confirms the idea and importance of cementing social ties (Granovetter 1973):

Well, that's the ones we know, yes. These are our friends. So, of course, we all support each other, exchange clothes or share advice, experiences, or help each other with money. But I repeat, they are very close to us. And others ... no, we do not have any relationship. (Interview with a representative of a foster family)

Some families are potentially ready to help families they do not know- "if we were asked to help" - even if they lack the time for social activities: "I have no such experience. But I think that if I were asked, I would participate. I would if someone needed me" (Interview with a low-income mother).

The most popular type of assistance is children's clothes exchanges or sharing information on childrearing and educational opportunities. This could also be advice on how to apply to state institutions or legal assistance. Families could help each other take care of children while a mother is away for a short period:

Of course, we share! We offer advice, for example, now as one family has issued documents, and we suggested what to do and how. (Interview with a representative of a low-income family 2) 
At least there is the baby clothes exchange. Then, if someone needs to visit the social service agencies and has no one to take care of the baby while they're there. Who can help? Not everyone has relatives ... usually there is a large family you know who could help. (Interview with a representative of a large family)

Families become very active when other families find themselves in serious trouble, such as in a fire. They spontaneously organize some cooperation, with the most widespread method being collecting clothing and other things the family in trouble might need. Often local schools become the center of civic activities like this, and they can provide a space for things to be collected. In small towns and rural areas, everyone finds out very quickly about such events, so in this case, civic activity is not limited by the social networks of friends, neighbors, and colleagues-a wider range of people, often not even involved with each other, can become involved:

If someone gets into trouble, the whole school would be involved in helping. We had a case when a house burned down on a winter's night, people ran naked into the snow-covered street with nothing. Later, the whole town knew the place to bring things; many people started donate; we got a lot. The victims of the fire even had a choice of what to take. If someone gets into such great trouble, the whole town would help. (Interview with a teacher supporting social activity of NGOs 1)

This is another good example that supports the idea of civically active population being much more successful if supported by an organization (in this case by the local school). Starting civic activity depends on the social ties and connections of initiators. In this example, enterprising parents joined first to share their ideas within the parental network. They then contacted a person they knew, their child's teacher. Her initial reaction as an organization representative was very important. In our case, the teacher facilitated the parents' civic activity, and it was successful. We found cases during our research when almost the same situation occurred, and the civic initiative of the parents was not supported by the representative of the organization they contacted, and the activity received no output. Another example of civic activity could also be an initiative of parents of schoolchildren wanting to share expenses for classroom activities, holidays, and school trips that low-income families could not afford. As teachers say, the other families in most of these cases supported such initiatives: "Class parent committees are usually in charge of such initiatives. Each class has a parent committee. It is a class community assistance: to collect, say, money and provide some help for those in need; they know who is in need" (Interview with a teacher supporting social activity of NGOs 1$)$.

Personal problems can help facilitate one's civic activity (Abramova and Sukhushina 2015). There are common problems such as questions of bringing up children, professional advice queries, and need for dialogue with similar families; tax payment and legal protection issues could also become grounds for civic activity of families. In this case, their self-organized interaction is also usually based on existing social relations and networks: "I joined [the NGO for foster parents] later. I came through this struggle in fact; we [the foster parents] had to be united, because otherwise you simply cannot 
survive alone. When we began to fight, we found them [the NGO]" (Interview with a foster mother, member of an NGO for foster parents).

Such spontaneous interactions can occasionally lead to regular civic activity for people. If they realized that formally organized forms of social activities were more efficient than individual ones, this could be a reason for creating an NGO. Existing NGOs could also be involved in the process to assist with queries. They could contact the NGO mainly if they already have some relations with NGO members or with the leader:

We [the head of an NG0 and I] have known each other for a long time, 25 years already. We are partners; I was involved as a sponsor. Several years ago, there were problems with the tax authorities. It was a common problem for all entrepreneurs, and we all gathered and wrote a letter with her [the leader of the organization] assistance. And people from the administration came in response to the letter. (Interview with an entrepreneur supporting an NG0)

Typically, spontaneous civic activities are not perceived by their initiators as "civic activity," but rather as expressions of a natural desire to help others in difficult situations, as a matter of social responsibility (excluding cases of organizing NGOs or becoming active members of existing NGOs). An important facet of civic activity is the confidence that joint efforts can be much more successful than individual ones, and sometimes this will be the only successful way. Informants who believe that everyone should solve their own problems as a rule are not involved in any kind of NGO activity, not even as consumers of services: "What's the point? Why? No one in this life will help you. Nobody, absolutely. My grandfather used to say so" (Interview with a low-income father).

Civically active people in many cases combine their civic activity with workplace duties, sometimes using the organization's facilities. This is usually possible for those who work with children in schools, clubs, and social institutions. It could be organizing an additional group for special kids in the club or assistance in applying for subsidies for families of students in a teachers' class:

Let's say, if a child has broken the law in some way, we investigate reasons, and we observe the family's living conditions, and his/her relationships with parents... people do sometimes go beyond their duties, what they're not obliged to. I do it just because it needs to be done, and there is no one else to do it. (Interview with a teacher supporting social activity of NGOs 2)

Respondents highlighted their own personal desires and motivation to be active when discussing helping those in need around them. This is especially important if a family in need does not see a way out and does not have the strength or knowledge of how to improve the situation; others could see an opportunity to find a solution even if they are unable to. Empathy is a much-valued motivation for social activity.

NGOs could be the stepping-stone for civic activity within local communities; a big role in the process of interpersonal communication and relationships is between NGOs and the local community. Involving their local community in civic activities is one of the most important functions of NGOs. NGOs could act as facilitators of grassroots civic activities, contribute to local community development, and help empower people. 


\section{CONCLUSIONS}

Many socially oriented NGOs in present-day Russia are similar to government bureaucratic organizations in terms of their organizational structure and functioning. De facto, they are not representatives of the local community, as they rely more on a customer-oriented approach: these NGOs become more like social services providers, rather than those engaging the local community in civic activities. To a certain extent, many of the existing NGOs are separated from the local community where they were originally established; therefore, $\mathrm{NGOs}$ are to a large degree perceived as being quasigovernmental structures providing social services. A rather weak relationship between NGOs and the population is one of the features of Russian third sector development.

People's attitudes towards NGOs are determined by the level of their civic activity. Civically active people are more likely to have positive attitudes towards NGOs even if they do not know much about them. They often become active participantsor even leaders - in NGO activities. Attitudes to NGOs are connected to perceptions of people's motives for participation, as well as with their ideas of the powers available to NGOs and their ability to solve people's problems.

Existing NGOs could be facilitators of grassroots civic activities, based to a large extent on informal social networks, making them more successful, contributing to local community development, and empowering people. NGOs could be examples and at the same time resources for future grassroots activities of the population. By taking part in the creation of an NGO, local people become not only clients or customers but partners and decision-makers as well.

\section{REFERENCES}

Abramova, Mariia, and Elena Sukhushina. 2015. “Otnoshenie naseleniia Tomskoi oblasti k obshchestvennym organizatsiiam kak marker grazhdanskogo obshchestva." Vestnik Tomskogo gosudarstvennogo universiteta: Filosofiia. Sotsiologiia. Politologiia 1(29):1-15.

Anheier, Helmut K. 2000. "Managing Non-Profit Organizations: Towards a New Approach." Civil Society Working Paper 1 (http://bigpushforward.net/wp-content/uploads/2011/10/lawoofnonprofitcomplexity1.pdf).

Banks, Nicola, and David Hulme. 2012. "The Role of NGOs and Civil Society in Development and Poverty Reduction." Brooks World Poverty Institute Working Paper no. 171, University of Manchester (https://ssrn.com/abstract=2072157).

Benevolenski, Vladimir B. 2014. "Tools of Government for Support of SONPOs in Russia: In Search of Cross-Sector Cooperation in the Delivery of Social Services." Basic Research Program Working Papers, WP BRP 17/PA/2014 (https://www.hse.ru/data/2014/08/26/1313067678/17PA2014.pdf).

Bindman, Eleanor. 2015. "The State, Civil Society and Social Rights in Contemporary Russia." East European Politics 31(3):342-360.

Blonin, Vladimir A., Nina N. Ivashinenko, and Dmitrii G. Strelkov. 2008. “Problemy i perspektivy razvitiia grazhdanskogo obshchestva v Nizhegorodskoi oblasti: Integratsiia NKO." Vestnik nizhegorodskogo universiteta im. N. I. Lobachevskogo 2:250-258.

Cheskin, Ammon, and Luke March. 2015. "State-Society Relations in Contemporary Russia: New Forms of Political and Social Contention." East European Politics 31(3):261-273.

Cook, Linda J., and Elena Vinogradova. 2006. "NGOs and Social Policy-Making in Russia's Regions." Problems of Post-Communism 53(5):28-41.

Crotty, Jo. 2009. "Making a Difference? NG0s and Civil Society Development in Russia." Europe-Asia Studies 61(1):85-108. 
Evans, Alfred B., Laura A. Henry, and Lisa McInstosh Sundrom. 2005. Russian Civil Society: A Critical Assessment. Armonk, NY: M. E. Sharpe.

Fell, Ben, and Miles Hewstone. 2015. "Psychological Perspectives on Poverty: A Review of Psychological Research into the Causes and Consequences of Poverty." Joseph Rowntree Foundation. Retrieved January 26, 2018 (https://www.jrf.org.uk/report/psychological-perspectives-poverty).

Fisher, Liz. 2013. "Transformational Leadership among Grassroots Social Service Organizations." Community Development 44(3):292-304.

Granovetter, Mark S. 1973. "The Strength of Weak Ties." American Journal of Psychology 78(6):1360-1380.

Hale, Henry. 2002. "Civil Society from Above? Statist and Liberal Models of State-Building in Russia." Demokratizatsiya 10(3):306-321.

Hemment, Julie. 2012. “Nashi, Youth Voluntarism, and Potemkin NGOs: Making Sense of Civil Society in Post-Soviet Russia." Slavic Review 71(2):234-260.

Henderson, Sarah L. 2002. "Selling Civil Society: Western Aid and the Nongovernmental Organization Sector in Russia." Comparative Political Studies 35(2):139-167.

Henry, Laura A. 2006. "Shaping Social Activism in Post-Soviet Russia: Leadership, Organizational Diversity, and Innovation." Post-Soviet Affairs 22(2):99-124.

Howard, Marc M. 2003. The Weakness of Civil Society in Post-Communist Europe. Cambridge: Cambridge University Press.

Ivashinenko, Nina N. 2014. "Searching for a New Approach to Face Poverty on the Local Level: A Case Study in a Small Russian Town." Debatte: Journal of Contemporary Central and Eastern Europe 22(3):403-419.

Ivashinenko, Nina, and Natal'ia Rimashevskaia, eds. 2013. Partisipatornyi podkhod $v$ povyshenii kachestva zhizni naseleniya. Nizhniy Novgorod, Russia: Izdatel'stvo Nizhegorodskogo gosudarstvennogo universiteta imeni N. I. Lobachevskogo.

Kay, Rebecca. 2000. Russian Women and Their Organizations: Gender, Discrimination, and Grassroots Women's Organizations in Russia, 1991-1996. Houndmills, UK: Macmillan Press.

Kiseleva, Tat'iana. 2013. "Issledovanie dominiruiushchei motivatsii k uchastiiu v dobrovol'cheskoi deiatel'nosti." Iaroslavskii pedagogicheskii vestnik 2(2):44-48.

Kosova, Ul'iana A. 2012. "Motivatsiia volonterskoi deiatel'nosti." Vestnik KRAUNTs: Gumanitarnye nauki 20(2):123-127.

Kulmala, Meri. 2011. "The Russian State and Civil Society in Interaction: An Ethnographic Approach." Laboratorium: Russian Review of Social Research 3(1):51-83.

Levada-Tsentr. 2012. "Otnoshenie k NKO i zakonodatel'nym initsiativam v etoi oblasti." August 8. Retrieved January 21, 2018 (https://www.levada.ru/2012/08/01/otnoshenie-k-nko-i-zakonodatelnym-initsiativam-v-etoj-oblasti/).

Loktionova, Tat'iana A. 2012. "Istoriia vozniknoveniia i stanovleniia volonterstva v Rossii." Molodoi uchenyi 8:267-269.

Mersiianova, Irina V., and Lev I. Iakobson. 2009. Praktiki filantropii v Rossii: Vovlechennost'i otnoshenie k nim naseleniia. Moscow: Higher School of Economics.

Nikula, Jouko, and Nina Ivashinenko. 2017. "Foster Care Reform and Social Partnership in Nizhny Novgorod Region." Journal of Social Policy Studies 15(3):383-394.

Putnam, Robert. 1995. "Bowling Alone: America's Declining Social Capital." Journal of Democracy $6(1): 65-78$.

Richter, James. 1998. "Promoting Activism or Professionalism in Russia's Civil Society?" PONARS Policy Memo 51:1-4.

Sokolov, Aleksandr V. 2013. “Deiatel'nost' obshchestvennykh organizatsii: Otsenki naseleniia." Teoriia i praktika obshchestvennogo razvitiia 10:300-303.

Tarasenko, Anna, and Meri Kulmala. 2016. “Predstavitel'stvo interesov i sotsial'naia politika v Rossii: Veteranskie organizatsii kak posredniki mezhdu obshchestvom i gosudarstvom." Zhurnal issledovanii sotsial'noi politiki 14(4):551-568.

Teodorovich, Mikhail L. 2009. Bednost' kak sotsial'naia problema: Strategicheskii podkhod. Nizhniy Novgorod, Russia: Izdatel'stvo Nizhegorodskogo gosudarstvennogo universiteta imeni N. I. Lobachevskogo. 
Varyzgina, Alla A. 2014. “Effektivnost' obrashcheniia naseleniia za sotsial'nymi uslugami v nekommercheskie organizatsii." Zhenshchina $v$ rossiiskom obshchestve 71(2):87-94.

Varyzgina, Alla A., and Rebecca Kay. 2014. "Perceptions of Poverty in Small-Town Russia." Debatte: Journal of Contemporary Central and Eastern Europe 22(3):269-287.

VTsIOM. 2016. “Uroven' schast'ia v Rossii-2016." December 2. Retrieved January 21, 2018 (https:// wciom.ru/index.php?id=236\&uid=115976).

Iakimets, Vladimir N. 2002. “Osnovy, printsipy i mekhanizmy mezhsektornogo sotsial'nogo partnerstva v Rossii." PhD dissertation, University of St. Petersburg.

\section{APPENDIX}

List of interviews cited in the text

\begin{tabular}{|l|l|l|l|l|}
\hline$\#$ & NG0 & $\begin{array}{l}\text { Target group for NG0s } \\
\text { activity }\end{array}$ & $\begin{array}{l}\text { Year of } \\
\text { research }\end{array}$ & $\begin{array}{l}\text { Type of } \\
\text { residential } \\
\text { community }\end{array}$ \\
\hline 1 & $\begin{array}{l}\text { Self-organized NG0 for } \\
\text { foster families }\end{array}$ & Foster families & 2015 & City \\
\hline 2 & NG0 for foster parents & Foster families & 2011,2015 & City \\
\hline 3 & Women's council NG0 & Families at risk & 2010,2015 & City \\
\hline 4 & Children's NG0 1 & Families & 2015 & City \\
\hline 5 & Children's NG0 2 & Families & 2010,2015 & City \\
\hline 6 & Charity for children NG0 & Children & 2015 & Small town \\
\hline 7 & Public chambers & General & 2015 & City \\
\hline 8 & NG0 for large families 1 & Large families & 2010 & City \\
\hline 9 & NG0 for large families 2 & Large families & 2010 & City \\
\hline 10 & $\begin{array}{l}\text { TOS (self-managed local } \\
\text { association) }\end{array}$ & General & 2010 & City \\
\hline Individuals supporting NG0s' social activity & \multicolumn{2}{|l|}{} \\
\hline 1 & $\begin{array}{l}\text { Teacher supporting social } \\
\text { activity of NG0s 1 }\end{array}$ & Supports NG0s' social activity & 2011 & Small town \\
\hline 2 & $\begin{array}{l}\text { Teacher supporting social } \\
\text { activity of NG0s 2 }\end{array}$ & Supports NG0s' social activity & 2011 & Small town \\
\hline 3 & $\begin{array}{l}\text { Entrepreneur supporting } \\
\text { an NG0 }\end{array}$ & Supports NG0's social activity & 2011 & Small town \\
\hline 4 & Entrepreneur & Supports NG0s' social activity & 2011 & Small town \\
\hline
\end{tabular}

Families-participants in the study

\begin{tabular}{|l|l|l|}
\hline Year of research & Type of residential community & Number of families \\
\hline 2010 & City & 16 \\
\hline 2011 & Small towns & 18 \\
\hline 2013 & Small towns, rural areas & 8 \\
\hline 2015 & City & 10 \\
\hline Total & 52 \\
\hline
\end{tabular}




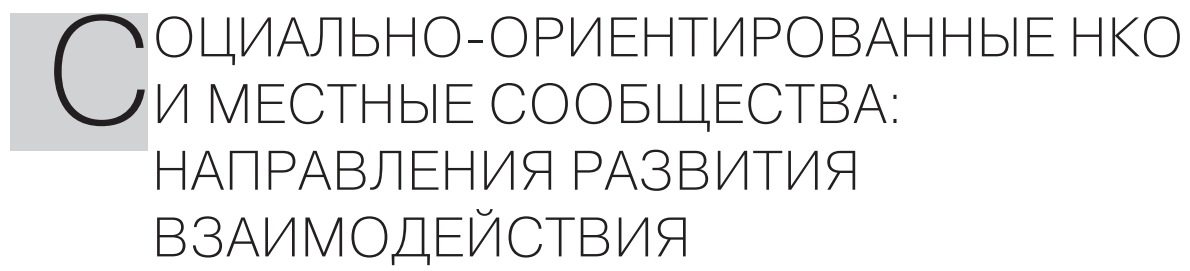

\section{Нина Ивашиненко, Алла Варызгина}

Нина Ивашиненко - профессор экономической социологии Нижегородского национального исследовательского университета им. Н. И. Лобачевского и почетный научный сотрудник Школы социальных и политических наук Университета Глазго. Адрес для переписки: Университетский пер., 7, Нижний Новгород, 603000, Россия.nina.ivashinenko@glasgow.ac.uk.

Алла Варызгина - лектор факультета социальных наук Нижегородского национального исследовательского университета им. Н. И. Лобачевского. Адрес для переписки: Университетский пер., 7, Нижний Новгород, 603000, Россия.varyzgina@mail.ru.

Статья посвящена изучению взаимодействия социально-ориентированных НКО с обращающимися к ним за помощью семьями с детьми, в том числе социально неблагополучными. Применение современных теоретических концепций изучения НКО как фактора и результата социальной активности на практике ограничивается тем фактом, что в российских регионах, особенно в сельских районах, такие организации зачастую существуют удаленно от местного сообщества и по сути своей ближе к государственным поставщикам социальных услуг. Были проанализированы факторы, которые могут способствовать сокращению дистанции между НКо и населением. Статья основана на результатах нескольких международных проектов, организованных в Нижегородской области в период с 2010 по 2015 год; Нижегородская область является среднестатистическим российским регионом по основным показателям социально-экономического развития. К участию в исследовании были приглашены лидеры НКО, оказывающих разнообразную поддержку семьям с детьми, как из областного центра, так и из малых городов Нижегородской области, а также представители семей, которые уже имеют опыт общения с НКО или потенциально заинтересованы в сотрудничестве с НКО, в частности многодетные семьи, семьи в трудной жизненной ситуации, приемные семьи. В статье показано, что характер взаимоотношений НКО и семей определяется позицией каждой из сторон: с одной стороны - особенностями создания НКО, особенностями их сотрудничества с государственными структурами, источниками финансирования деятельности НКО и набором предоставляемых социальных услуг; с другой стороны, уровень доверия к НКО, характер отношения населения к некоммерческим организациям, существующий у людей опыт общения с конкретными нк0, а также степень развитости сетей социальной поддержки в местном сообществе определяют и возможности, и препятствия расширения взаимодействия НКо и населения. Исследование взаимоотношений НКО с различными социальными группами населения важно для понимания процессов развития третьего сектора в России в целом, а также может быть полезным для руководителей и активных членов НКО в их повседневной деятельности.

Ключевые слова: НК0; местные сообщества; низовая общественная активность; социальные услуги для семей 